Biochemistry and Molecular Biology Unit, School of Dental Science, The University of Melbourne, 711, Elizabeth Street, Melbourne, Victoria 3000 , Australia

\section{A cell-associated protein complex of Porphyromonas gingivalis W50 composed of Arg- and Lys-specific cysteine proteinases and adhesins}

\author{
Peter S. Bhogal, Nada Slakeski and Eric C. Reynolds \\ Author for correspondence: Eric C. Reynolds. Tel +6139341 0270. Fax: +61393410236. \\ e-mail: eric_reynolds.dental@muwaye.unimelb.edu.au
}

Porphyromonas gingivalis has been associated with the development of adult periodontitis and cysteine proteinases with trypsin-like specificity have been implicated as major virulence factors. We have extracted the major cellassociated trypsin-like proteolytic activity of $P$. gingivalis W50 using mild sonication. Anion-exchange and gel-filtration FPLC of the sonicate revealed that Arg- and Lys-specific proteinase activity was associated with a $300 \mathrm{kDa}$ complex which could be dissociated into seven bands $(48,45,44,39,27,17$ and $15 \mathrm{kDa}$ ) by SDS-PAGE with the $44 \mathrm{kDa}$ band containing two different proteins as shown by $\mathrm{N}$-terminal sequence analysis. On further chromatography of the $300 \mathrm{kDa}$ complex on Arg-Sepharose the majority of the complex eluted from the affinity column as an undissociated complex. However, a small amount dissociated such that the Lys- and Arg-specific activities could be separated by eluting first with lysine then arginine, respectively. The $45 \mathrm{kDa}$ protein of the complex was purified by further anion-exchange FPLC in the presence of octyl$\beta$-D-glucopyranoside and was shown to be an Arg-specific, thiol-activated, calcium-stabilized cysteine proteinase. The $48 \mathrm{kDa}$ protein was also further purified in a similar fashion and shown to be a Lys-specific cysteine proteinase that was not inhibited by EDTA. The two $44 \mathrm{kDa}$ and the 39, 27, 17 and $15 \mathrm{kDa}$ proteins of the complex exhibit amino acid sequence homology and are proposed to be haemagglutinins/adhesins. The $\mathbf{4 5}$ kDa Arg-specific proteinase and one of the $44 \mathrm{kDa}$ adhesins as well as the 15, 17 and $27 \mathrm{kDa}$ adhesins are processed from the single polyprotein encoded by the gene designated prt $R$, with all proteins preceded by an Arg or Lys residue within the polyprotein. Similarly, the $48 \mathrm{kDa}$ Lys-specific proteinase, the 39 and $15 \mathrm{kDa}$ adhesins as well as the other $44 \mathrm{kDa}$ adhesin of the $300 \mathrm{kDa}$ complex are encoded by a single gene designated prtK, with all proteins preceded by an Arg or Lys residue within the polyprotein. The 39,15 and $44 \mathrm{kDa}$ adhesins of PrtK all exhibit high homology with the 44, 15, 17 and $27 \mathrm{kDa}$ adhesins encoded by prtR, particularly the $15 \mathrm{kDa}$ proteins which are identical. The cell-associated proteinase-adhesin complex, designated PrtR-PrtK, is therefore composed of the two gene products, the mature PrtR (160 kDa) and mature PrtK (163 kDa) that are further proteolytically processed (most likely autolytically) to release proteinase and adhesin domains that remain non-covalently associated. The fully processed PrtR-PrtK complex comprises the cysteine proteinases PrtR45 and PrtK48 and seven sequence-related adhesin molecules, PrtR44, PrtR15, PrtR17, PrtR27 and PrtK39, PrtK15 and PrtK44. We propose that this proteinase-adhesin complex is a major virulence factor for $P$. gingivalis 


\section{involved in the evasion of host defence and in the assimilation of haem and peptides.}

Keywords: Porphyromonas gingivalis, cell-associated cysteine proteinases, adhesins

\section{INTRODUCTION}

Periodontal diseases are chronic inflammatory diseases of the supporting tissues of the teeth, associated with bacteria and range from the relatively mild form of gingivitis, the non-specific, reversible inflammation of gingival tissue, to the more aggressive forms of periodontitis which are characterized by the destruction of the tooth's supporting structures. Periodontitis is associated with a subgingival infection of a consortium of specific Gram-negative bacteria that leads to the destruction of the periodontium and is a major public health problem. One bacterium that has attracted considerable interest is Porphyromonas gingivalis as the recovery of this micro-organism from adult periodontitis lesions can be up to $50 \%$ of the subgingival anaerobically cultivable flora (Christersson et al., 1989; Slots, 1982), whereas it is rarely recovered, and then in low numbers, from healthy sites (Moore et al., 1991). A proportional increase in the level of $P$. gingivalis in subgingival plaque has been associated with an increased severity of periodontitis (Mayrand \& Holt, 1988; Socransky et al., 1991) and eradication of the microorganism from the cultivable subgingival microbial population is accompanied by resolution of the disease (Loesche et al., 1981; Van Dyke et al., 1988). Holt et al. (1988) have demonstrated the progression of periodontitis lesions in non-human primates with the subgingival implantation of $P$. gingivalis. Further, immunization with killed whole $P$. gingivalis cells significantly reduced progression of periodontitis associated with the indigenous or $P$. gingivalis-superinfected subgingival flora in this non-human primate model (Persson et al., 1994). These findings in both animals and humans suggest a major role for $P$. gingivalis in the development of adult periodontitis.

$P$. gingivalis is a black-pigmented, anaerobic, asaccharolytic, Gram-negative rod that obtains energy from the metabolism of specific a mino acids. The micro-organism has an absolute growth requirement for iron, preferentially in the form of haem or its $\mathrm{Fe}$ (III) oxidation product haemin and when grown under conditions of excess haemin is highly virulent in experimental animals (Marsh et al., 1994). A number of virulence factors have been implicated in the pathogenicity of $P$. gingivalis including the capsule, adhesins, cytotoxins and extracellular hydrolytic enzymes. In particular, proteases have received a great deal of attention for their ability to degrade a broad range of host proteins including structural proteins and others involved in defence. The proteins that have been shown to be substrates for $P$. gingivalis proteolytic activity include collagen types I and IV, fibronectin, fibrinogen, laminin, complement and plasma clotting cascade proteins, $\alpha_{1}$-antitrypsin, $\alpha_{2}$-macroglobulin, antichymotrypsin, antithrombin III, antiplasmin, cystatin C, IgG and IgA, (Grenier, 1996; Pike et al., 1996; Carlsson et al., 1984; Fujimura et al., 1993; Grenier et al., 1989; Lantz et al., 1991; Mayrand \& Holt, 1988; Smalley et al., 1989a ; Sorsa et al., 1987; Sundqvist et al., 1985). The major proteolytic activities associated with this organism have been defined by substrate specificity and are 'trypsin-like', that is cleavage on the carboxyl side of arginyl and lysyl residues (Yoshimura et al., 1984) and collagenolytic (Toda et al., 1984) although other minor activities have been reported (Grenier \& Mayrand, 1993).

$P$. gingivalis trypsin-like proteolytic activity has been shown to degrade complement, generating biologically active C5a (Wingrove et al., 1992; Jagels et al., 1996), to impair the phagocytic and other functions of neutrophils by modifying surface receptors (Jagels et al., 1996; Cutler et al., 1995; Kadowaki et al., 1994), and to abrogate the clotting potential of fibrinogen thus prolonging plasma clotting time (Imamura et al., 1995a). The trypsin-like proteolytic activity of $P$. gingivalis is also associated with vascular disruption and enhanced vascular permeation through the activation of the kallikrein-kinin cascade (Imamura et al., 1994, 1995b). $P$. gingivalis spontaneous mutants with reduced trypsinlike activity as well as wild-type cells treated with the trypsin-like protease inhibitor $N \alpha$-p-tosyl-L-lysine chloromethyl ketone (TLCK) are avirulent in animal models (McKee et al., 1988; Smalley et al., 1989b; Kesavalu et al., 1996). Further, Marsh et al. (1994) have shown that $P$. gingivalis grown under controlled, haemin-excess conditions expressed more trypsin-like and less collagenolytic activity and were more virulent in mice relative to cells grown under haemin-limited but otherwise identical conditions. The increased expression of the trypsin-like activity by the more virulent $P$. gingivalis led the authors to speculate that the trypsinlike proteolytic activity may be the major determinant for infection or disease.

These studies suggest a major role for the trypsin-like protease(s) of $P$. gingivalis in the pathogenesis of periodontitis and therefore have led to considerable interest and endeavour to purify and biochemically characterize these proteins. The most extensive work in characterization of these enzymes has been by Travis and co-workers who have purified Arg- and Lys-specific proteinases from the culture fluid of $P$. gingivalis $\mathrm{H} 66$ (Chen et al., 1992; Pike et al., 1994). The Arg-specific proteinase of the culture fluid was a $50 \mathrm{kDa}$, EDTAsensitive, cysteine proteinase designated Arg-gingipain (Chen et al., 1992). The Lys-specific enzyme of the culture fluid was proposed to be a $60 \mathrm{kDa}$ cysteine proteinase designated Lys-gingipain and this enzyme 
was not EDTA sensitive (Pike et al., 1994). Notwithstanding this extensive characterization of the culture fluid trypsin-like proteinases, the cell-associated trypsinlike proteases of $P$. gingivalis remain to be comprehensively characterized. In this paper we characterize the cell-associated trypsin-like proteinases of $P$. ging $i$ valis W50 as complexes composed of Arg-specific and Lys-specific cysteine proteinases and sequence-related adhesins encoded by the two genes prt $R$ and $p r t K$.

\section{METHODS}

Bacterial strain and growth conditions. Lyophilized cultures of Porphyromonas gingivalis W50 (McKee et al., 1986) were kindly provided by Dr P. Marsh (PHLS Centre for Applied Microbiology and Research, Wiltshire, UK). P. gingivalis W50 was grown anaerobically at $37^{\circ} \mathrm{C}$ on lysed horse blood agar and in modified BM medium containing $1 \mu \mathrm{g}$ haemin $\mathrm{ml}^{-1}$ (McKee et al., 1986). Bacteria were maintained on lysed horse blood plates by routine passage ( $<10$ passages) and used to inoculate batch cultures. Batch culture growth was monitored at $650 \mathrm{~nm}$ using a spectrophotometer (Perkin-Elmer model $295 \mathrm{E}$ ). Culture purity was checked routinely by Gram stain, microscopic examination and by a variety of biochemical tests according to Slots (1982). Stocks were maintained as lyophilized cultures.

Enzyme purification. $P$. gingivalis cells were grown in batch culture $(51)$ to late exponential phase, harvested by centrifugation $\left(5000 \mathrm{~g}, 20 \mathrm{~min}, 4^{\circ} \mathrm{C}\right)$, and washed with TC buffer (20 mM Tris/ $\mathrm{HCl}, \mathrm{pH} 7 \cdot 4$, and $5 \mathrm{mM} \mathrm{CaCl}_{2}$ ) containing $50 \mathrm{mM} \mathrm{NaCl}$. The washed cells were resuspended in $160 \mathrm{ml}$ TC buffer containing $50 \mathrm{mM} \mathrm{NaCl}$ and subjected to mild sonication for $15 \mathrm{~min}$ at $4{ }^{\circ} \mathrm{C}$ using a Branson Sonifier 250 with an output control of 3 and a $50 \%$ duty cycle. The sonicate was centrifuged $\left(100000 \mathrm{~g}, 30 \mathrm{~min}, 4^{\circ} \mathrm{C}\right)$ and the supernatant filtered $(0.22 \mu \mathrm{m})$ prior to anion-exchange FPLC. The sonicate was applied to an anion-exchange column (Hiload XK 16/10 Q Sepharose, Pharmacia-LKB) cooled to $4{ }^{\circ} \mathrm{C}$, in multiple injections using a $50 \mathrm{ml}$ superloop (Pharmacia-LKB). The sample was eluted using a linear gradient of $0-100 \%$ buffer B over $90 \mathrm{~min}$ at a flow rate of $2.0 \mathrm{ml} \mathrm{min}{ }^{-1}$. The eluant was monitored at $280 \mathrm{~nm}$ and collected in $6 \mathrm{ml}$ fractions using a Frac 100 fraction collector (Pharmacia-LKB). Buffer A was TC buffer containing $50 \mathrm{mM} \mathrm{NaCl}$ and buffer $\mathrm{B}$ was TC buffer containing $500 \mathrm{mM} \mathrm{NaCl}$. Fractions were analysed for proteolytic and amidolytic activity using azocasein (A-2765, Sigma), benzoyl-L-Arg- $p$-nitroanilide (Bz-LArg- $p$ NA, Sigma) and benzyloxycarbonyl-L-Lys- $p$-nitroanilide (z-L-Lys- $p$ NA, Calbiochem), vide infra. Anion-exchange fractions containing the majority of proteolytic/amidolytic activity were pooled, washed and concentrated in TC buffer containing $150 \mathrm{mM} \mathrm{NaCl}$ using a Centricon-10 micro-concentrator (Amicon). The sample was divided into two aliquots and each was independently applied to a gel-filtration column (Superose 12, HR 10/30, Pharmacia-LKB) using TC buffer containing $150 \mathrm{mM} \mathrm{NaCl}$ at a flow rate of $0.3 \mathrm{ml} \mathrm{min}{ }^{-1}$. The eluant was monitored at $280 \mathrm{~nm}$ and peaks collected using a Frac 100 fraction collector. The molecular masses of eluant peaks were determined using molecular mass gel filtration standards (Pharmacia-LKB). The peak containing the majority of the proteolytic/amidolytic activity was applied at a flow rate of $0.1 \mathrm{ml} \mathrm{min}^{-1}$ to an Arg-Sepharose column $(5 \mathrm{ml}$ arginine-Sepharose 4B beads, HR 5/5 column, PharmaciaLKB). The column was washed with $500 \mathrm{mM} \mathrm{NaCl}$ and reequilibrated with TC buffer containing $50 \mathrm{mM} \mathrm{NaCl}$. The

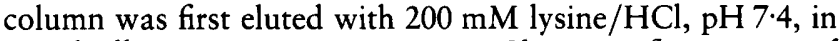
TC buffer containing $50 \mathrm{mM} \mathrm{NaCl}$ at a flow rate of $0.1 \mathrm{ml} \mathrm{min}{ }^{-1}$. This was followed by $750 \mathrm{mM}$ lysine $/ \mathrm{HCl}$, $\mathrm{pH} 7 \cdot 4$, in the same buffer. The column was then reequilibrated with TC buffer containing $50 \mathrm{mM} \mathrm{NaCl}$ and then eluted with $200 \mathrm{mM}$ arginine $/ \mathrm{HCl}, \mathrm{pH} 7 \cdot 4$, in TC buffer containing $50 \mathrm{mM} \mathrm{NaCl}$ at a flow rate of $0.1 \mathrm{ml} \mathrm{min}^{-1}$. The eluant was monitored at $280 \mathrm{~nm}$ and peaks collected using a Frac 100 fraction collector. The peaks eluted from the ArgSepharose by $200 \mathrm{mM}$ lysine and $200 \mathrm{mM}$ arginine were equilibrated with TC buffer containing $50 \mathrm{mM} \mathrm{NaCl}$ and $1.0 \%$ octyl- $\beta$-D-glucopyranoside and then applied to a Mono $\mathrm{Q}$ (HR 5/5) anion-exchange column and eluted using a linear gradient of $0-100 \%$ buffer $B$ at a flow rate of $1.0 \mathrm{ml} \mathrm{min}$. $^{-1}$. Buffer A was TC buffer containing $50 \mathrm{mM} \mathrm{NaCl}$ and $0.1 \%$ octyl- $\beta$-D-glucopyranoside and buffer B was TC buffer containing $500 \mathrm{mM} \mathrm{NaCl}$ and $0 \cdot 1 \%$ octyl- $\beta$-D-glucopyranoside. The eluant was monitored at $280 \mathrm{~nm}$ and eluant peaks collected using a Frac 100 fraction collector.

Enzyme characterization. Azocasein, Bz-L-Arg- $p$ NA and $z-L-$ Lys- $p$ NA were used to routinely assay FPLC fractions for proteolytic and amidolytic activity. A sample of each fraction $(20-200 \mu \mathrm{l})$ was incubated at $37^{\circ} \mathrm{C}$ with azocasein $\left(5 \mathrm{mg} \mathrm{ml}^{-1}\right.$ final concentration) in TC buffer, $\mathrm{pH} 8 \cdot 0$, containing $150 \mathrm{mM}$ $\mathrm{NaCl}$ and $10 \mathrm{mM}$ cysteine. For azocasein the reaction was stopped by the addition of $30 \%$ trichloroacetic acid at $4{ }^{\circ} \mathrm{C}$. After centrifugation and neutralization of the supernatant with $5 \mathrm{M} \mathrm{NaOH}$, the absorbance was measured at $440 \mathrm{~nm}$ using a spectrophotometer (Perkin Elmer, model 552).

For the synthetic chromogenic substrates, samples of each chromatographic fraction $(5-50 \mu \mathrm{l})$ were incubated at $25^{\circ} \mathrm{C}$ with $\mathrm{Bz}-\mathrm{L}-\mathrm{Arg}-\mathrm{pNA}$ or $\mathrm{z}-\mathrm{L}-\mathrm{L} y \mathrm{~s}-\mathrm{pNA}(1.0 \mathrm{mM}$ final concentration) in a total volume of $350 \mu 100 \mathrm{mM}$ Tris/HCl buffer, pH $8 \cdot 0$, containing $150 \mathrm{mM} \mathrm{NaCl}, 10 \mathrm{mM}$ cysteine and $5 \mathrm{mM}$ $\mathrm{CaCl}_{2}$. Inhibitors and activators were added to the purified enzymes in $100 \mathrm{mM}$ Tris $/ \mathrm{HCl}$ buffer, $\mathrm{pH} \mathrm{8.0,} \mathrm{containing}$ $150 \mathrm{mM} \mathrm{NaCl}$ and $1.0 \mathrm{mM}$ 2-mercaptoethanol. Absorbance was measured at $410 \mathrm{~nm}$ using a Hewlett Packard 8452A Diode Array spectrophotometer and the amidolytic activity expressed in $U$, where $U=\mu \mathrm{mol}$ substrate converted $\min ^{-1}$ at $25^{\circ} \mathrm{C}$. Trypsin (EC 3.4.21.4, T 8253, Sigma) was used as a standard. The protein concentration of FPLC fractions and purified samples was determined using the Bradford protein assay (Bio-Rad) with BSA as a standard.

A sample of the gel-filtration chromatographic fraction $(20 \mu \mathrm{l})$ exhibiting the major proteolytic and amidolytic activity was incubated for $4 \mathrm{~h}$ at $37^{\circ} \mathrm{C}$ with $10 \mathrm{mg} \mathrm{ml}^{-1}$ of pure $\alpha_{\mathrm{s1}}$-casein (Reynolds, 1987) dissolved in TC buffer, pH 8.0, containing $150 \mathrm{mM} \mathrm{NaCl}$ and $50 \mathrm{mM} 2$-mercaptoethanol. Following incubation, the sample was equilibrated in $0.1 \%(\mathrm{v} / \mathrm{v})$ trifluoroacetic acid (TFA) dissolved in Milli $Q$ water (buffer A). The sample was then applied to an HPLC reversed-phase analytical column $(\mathrm{C} 8,7 \mu \mathrm{m}, 4.6 \mathrm{~mm} \times 220 \mathrm{~mm}$, Brownlee Aquapore RP300, Applied Biosystems) and peptides eluted using a linear gradient of $0-100 \%$ buffer $B$ over $40 \mathrm{~min}$ at a flow rate of $1 \mathrm{ml} \mathrm{m^{-1 }}$ (140A solvent delivery system). Buffer B was $80 \%$ $(\mathrm{v} / \mathrm{v})$ acetonitrile in $0.1 \%(\mathrm{v} / \mathrm{v})$ TFA in Milli $\mathrm{Q}$ water. The eluant was monitored at $214 \mathrm{~nm}$ using a $1000 \mathrm{~S}$ diode array detector (Applied Biosystems). Peaks were collected manually and peptides identified using a combination of amino acid composition and sequence analyses as described previously (Reynolds et al., 1994).

SDSPAGE, protein transblot and $\mathbf{N}$-terminal sequence analysis. SDS-PAGE was performed using a Mini protean II electrophoresis system (Bio-Rad) with $12 \%$ (w/v) $1 \mathrm{~mm}$ 
separating gels, overlaid with $5 \%$ stacking gels (Laemmli, $1970)$. Each sample $(20 \mu \mathrm{l})$ was added to $10 \mu \mathrm{l}$ of sample buffer [0.5 M Tris $/ \mathrm{HCl}, \mathrm{pH} 6.8,10.0 \%$ (w/v) SDS, $0.05 \%(\mathrm{w} / \mathrm{v})$ bromophenol blue $(75 \%, v / v)$ and glycerol $(25 \%, v / v)]$. In some cases the sample buffer also contained $5 \%(\mathrm{v} / \mathrm{v}) 2$ mercaptoethanol or $3 \mathrm{mM}$ TLCK. After mixing, the samples were either held at room temperature (non-boiled) or heated at $100{ }^{\circ} \mathrm{C}$ (boiled) for $4 \mathrm{~min}$. SDS-PAGE was performed using a current of $30-50 \mathrm{~mA}$ and a potential difference of $\leqslant 200 \mathrm{~V}$. For silver staining, gels were fixed in methanol/ water/acetic acid ( $45: 45: 10$, by vol.), washed in Milli $Q$ water, reduced with $5 \mu \mathrm{g}$ dithiothreitol $\mathrm{ml}^{-1}$ and then washed in Milli $\mathrm{Q}$ water, all for $30 \mathrm{~min}$ periods. Gels were then stained for 20 min with $0.1 \%(\mathrm{w} / \mathrm{v}) \mathrm{AgNO}_{3}$ and developed with $3 \%$ $(\mathrm{w} / \mathrm{v})$ sodium carbonate containing $0.1 \%(\mathrm{v} / \mathrm{v})$ formaldehyde and development was stopped with glacial acetic acid according to the method of Merril et al. (1982). For Coomassie blue staining, gels were fixed in $12 \%$ TCA and stained overnight using $0 \cdot 1 \%(\mathrm{w} / \mathrm{v})$ purified Coomassie brilliant blue $\mathrm{G} 250$ in $2 \%(\mathrm{w} / \mathrm{v})$ phosphoric acid, $6 \%(\mathrm{w} / \mathrm{v})$ ammonium sulphate (Neuhoff et al., 1985). Gels were destained with methanol/water/acetic acid $(50: 40: 10$, by vol.). Proteins were transferred onto a PVDF membrane [Problott, Applied Biosystems Inc. (ABI)] for sequence analysis using a transblot cell (Bio-Rad). PVDF membrane was wetted in 100\% methanol and soaked in transfer buffer (10 mM CAPS $/ 10 \%$ methanol, $\mathrm{pH} 11 \cdot 5)$. Transfer was performed using a potential difference of $60 \mathrm{~V}(300 \mathrm{~mA})$ for $90 \mathrm{~min}$. Membranes were briefly stained using $0 \cdot 1 \%(\mathrm{w} / \mathrm{v})$ Coomassie brilliant blue R 250 in methanol/water/acetic acid (5:5:1, by vol.). Protein bands were exised, destained for 10-30 s in 50\% methanol and N-terminal sequences determined using a Hewlett Packard 1005A protein sequencer or a modified ABI 471-02A protein sequencer fitted with a blott cartridge.

\section{RESULTS}

The ultrasonication procedure was effective in releasing the cell-associated Arg- and Lys-specific proteolytic activity of $P$. gingivalis W50 and 15 min was required for maximal release of activity. The sonicate of $P$. gingivalis W50 cells contained $0.30 \mathrm{mg}$ protein $\mathrm{ml}^{-1}$ and 2.6 and

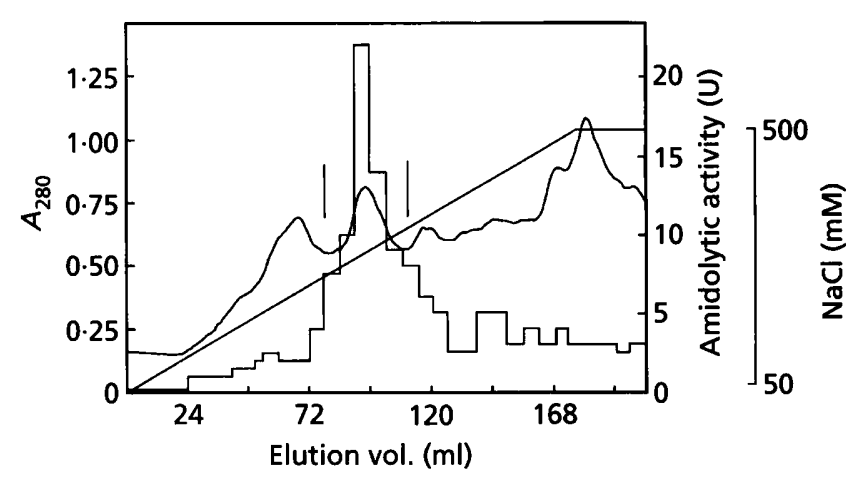

Fig. 1. Anion-exchange FPLC of a $P$. gingivalis W50 sonicate. The sonicate in TC buffer containing $50 \mathrm{mM} \mathrm{NaCl}$ was applied to a Hiload XK $16 / 10$ Q-Sepharose column and eluted using a linear gradient of $0-100 \%$ buffer B over 90 min at a flow rate of $2.0 \mathrm{ml} \mathrm{min} \mathrm{m}^{-1}$. Fractions $(6 \mathrm{ml})$ were assayed for proteolytic and amidolytic activity using azocasein, Bz-L-Arg-pNA and $Z-L-$ Lys-pNA. The amidolytic activity of each $6 \mathrm{ml}$ fraction with Bz-LArg-pNA is shown by the histogram.

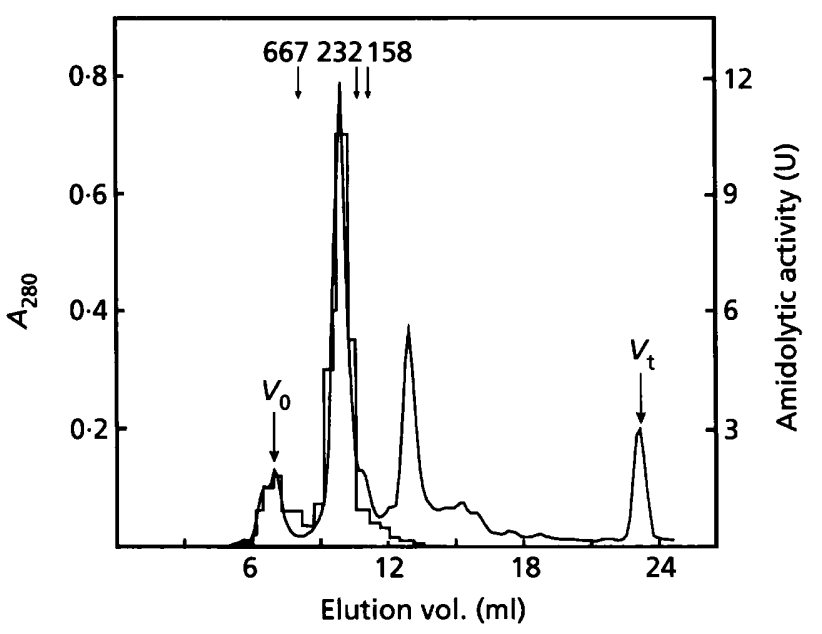

Fig. 2. Gel-filtration FPLC of the pooled and concentrated fractions from Q-Sepharose anion-exchange FPLC containing proteolytic/amidolytic activity. Anion-exchange fractions containing the major peak of proteolytic/amidolytic activity were pooled, equilibrated in TC buffer containing $150 \mathrm{mM}$ $\mathrm{NaCl}$, concentrated and divided into two aliquots which were each independently applied to a gel-filtration column (Superose $12 \mathrm{HR}$ 10/30) and eluted using the same buffer at a flow rate of $0.3 \mathrm{ml} \mathrm{min}^{-1}$. Fractions $(0.5 \mathrm{ml})$ were assayed for proteolytic and amidolytic activity. Bz-L-Arg-pNA amidolytic activity is shown by the histogram. $V_{0}$ and $V_{t}$ indicate the void and total volumes of the column, respectively. The elution volumes of the standard proteins thyroglobulin $(667 \mathrm{kDa})$, catalase $(232 \mathrm{kDa})$ and aldolase $(158 \mathrm{kDa})$ are marked.

$1.3 \mu \mathrm{mol} \mathrm{min}^{-1}$ (mg protein) ${ }^{-1}$ activity at $25^{\circ} \mathrm{C}$ with $1.0 \mathrm{mM}$ Bz-L-Arg- $p$ NA and z-L-Lys- $p$ NA as substrate, respectively. The crude sonicate was subjected to $\mathrm{Q}-$ Sepharose anion-exchange FPLC and a representative chromatogram is presented in Fig. 1. Proteolytic/ amidolytic activity eluted as one major peak between 246-320 mM NaCl (Fig. 1) which was collected, concentrated using a Centricon-10 (Amicon) and then applied to the Superose 12 gel-filtration column (Fig. 2). Molecular mass gel filtration standards were used to determine the molecular masses of the peaks obtained and the major peak, which also exhibited the major proteolytic/amidolytic activity, corresponded to $300 \mathrm{kDa}$ (Fig. 2). Proteolytic/amidolytic activity was also associated with the high-molecular-mass material $\left(0.6->2.0 \times 10^{6} \mathrm{Da}\right)$ eluted from the gel filtration column. The $300 \mathrm{kDa}$ gel filtration peak contained seven bands at 48, 45, 44, 39, 27, 17 and $15 \mathrm{kDa}$ on SDS-PAGE analysis (Fig. 3). The seven bands were transblotted and subjected to $\mathrm{N}$-terminal sequence analysis (Table 1 ). This analysis revealed that the $44 \mathrm{kDa}$ band contained two proteins and the $\mathrm{N}$-terminal sequences of these two $44 \mathrm{kDa}$ proteins were assigned after further purification. The $\mathrm{N}$-terminal sequence of one of the $44 \mathrm{kDa}$ proteins was identical to that of the $17 \mathrm{kDa}$ protein and the $39 \mathrm{kDa}$ and $27 \mathrm{kDa}$ proteins also had identical $\mathrm{N}$-termini (Table 1).

Repeated gel-filtration analyses of the Q-Sepharosepurified material or crude sonicates indicated that the 


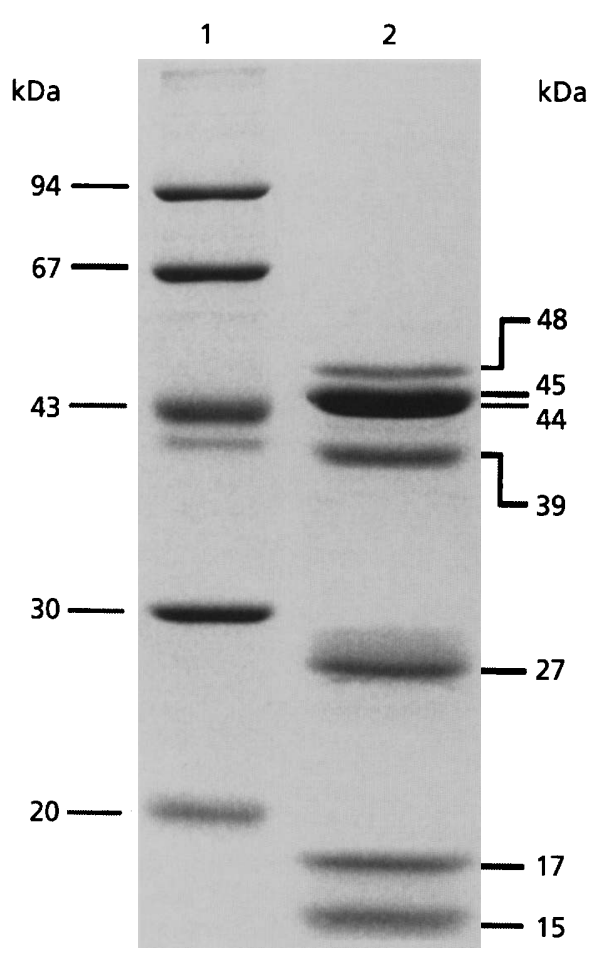

Fig. 3. SDS-PAGE (boiled-reduced conditions) of the $300 \mathrm{kDa}$ peak from gel-filtration (Superose 12 HR 10/30) FPLC. Lane 1, Pharmacia molecular-mass standards $(\mathrm{kDa})$; lane 2, $300 \mathrm{kDa}$ peak from gel-filtration FPLC. Gel stained with Coomassie blue.

major proteolytic/amidolytic activity was associated with a peak corresponding to $300 \mathrm{kDa}$ and higher molecular mass $\left(0.6->2 \times 10^{6} \mathrm{Da}\right)$ material that when boiled in SDS and subjected to SDS-PAGE analysis contained the same seven bands at 48, 45, 44, 39, 27, 17 and $15 \mathrm{kDa}$ (Fig. 3). The $300 \mathrm{kDa}$ complex was also observed when the sonication and chromatography were performed in the presence of reducing agent such that the association of the proteins in the complex was not by $\downarrow \downarrow \downarrow-10 \quad 14 \quad 20$

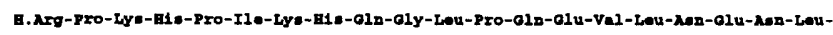

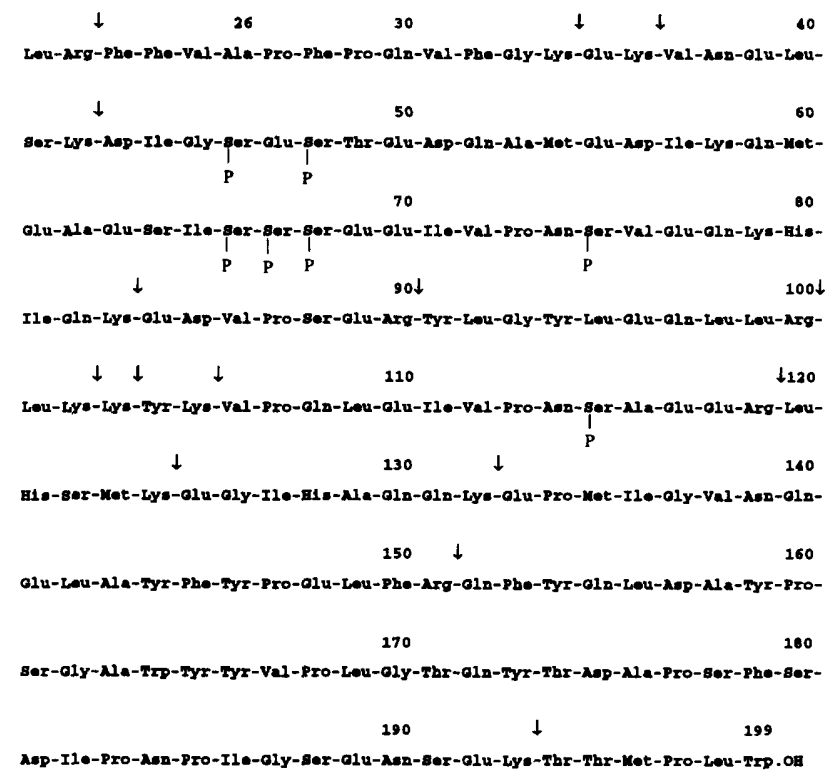

Fig. 4. Specific cleavage sites (marked with arrows) of $\alpha_{51}$-casein by the proteolytic/amidolytic peak from gel-filtration FPLC corresponding to $300 \mathrm{kDa}$. The protein $\alpha_{\mathrm{s} 1}$-casein was cleaved on the carboxyl side of arginyl and lysyl residues only.

intermolecular disulphide bond formation. SDS-PAGE without boiling of the $300 \mathrm{kDa}$ complex produced bands corresponding to the relative molecular masses of approximately $300,150,104-115,87,76$ and $66 \mathrm{kDa}$ (data not shown).

The $300 \mathrm{kDa}$ gel-filtration protein complex was incubated with $\alpha_{\mathrm{s} 1}$-casein. The $\alpha_{\mathrm{s} 1}$-casein peptides released by the action of the proteolytic activity of the $300 \mathrm{kDa}$ complex were purified by RP-HPLC and identified by amino acid composition and sequence analyses. The sites of $\alpha_{\mathrm{si}}$-casein cleavage by the $300 \mathrm{kDa}$ complex were the carboxyl side of arginyl and lysyl residues only (Fig. 4). All arginyl and lysyl residues of $\alpha_{\mathrm{s} 1}$-casein were

Table 1. N-terminal sequences of proteins in the $300 \mathrm{kDa}$ complex separated by SDSPAGE

\begin{tabular}{|cl|}
\hline $\begin{array}{c}\text { Band } \\
(\mathbf{k D a})\end{array}$ & \multicolumn{1}{c|}{ N-terminal sequence } \\
\hline $48^{*}$ & DVYTDHGDLYNTPVRML \\
$45 \dagger$ & YTPVEEKQNGRMIVIVAKKYEGD \\
$44 \dagger$ & SGQAEIVLEAHDVWNDGSGYQILLDADHDQYGQVI PSDTHFL \\
$44^{*}$ & PQSVWIERTVDLPAGTKYVAFR \\
$39^{*}$ & ANEAKVVLAADNVWGDNTGYQFLLDA \\
$27 \dagger$ & ANEAKVVLAADNVWGDNTGYQFLLDA \\
$17 \dagger$ & PQSVWIERTVDLPAGTKYVAFR \\
$15^{*} \dagger$ & ADFTETFESSTHGEAPAEWTTIDA \\
\hline
\end{tabular}

\footnotetext{
* Proteins eluted from Arg-Sepharose by $200 \mathrm{mM}$ lysine.
}

† Proteins eluted from Arg-Sepharose by $200 \mathrm{mM}$ arginine. 


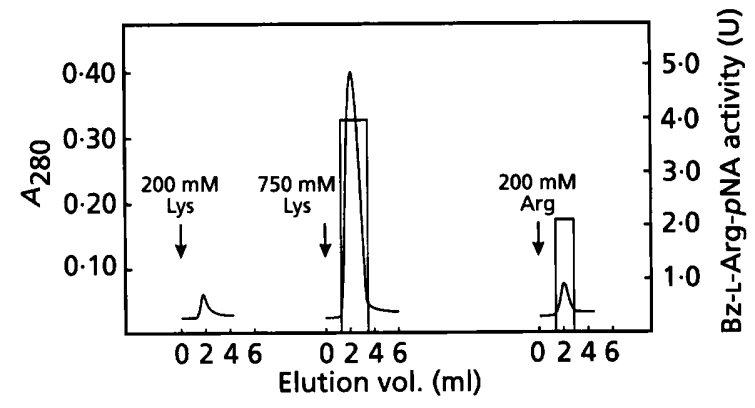

Fig. 5. Arg-Sepharose FPLC of the $300 \mathrm{kDa}$ gel-filtration peak exhibiting Arg- and Lys-specific proteolytic activity. Gelfiltration fractions containing the major peak of proteolytic activity ( $300 \mathrm{kDa}$ ) were pooled and applied to an Arg-Sepharose column ( $5 \mathrm{ml} \mathrm{Arg-Sepharose} \mathrm{4B)}$ and washed with TC buffer containing $50 \mathrm{mM} \mathrm{NaCl}$ at $0.1 \mathrm{ml} \mathrm{min}^{-1}$ until the baseline returned to zero. The column was further washed with $500 \mathrm{mM}$ $\mathrm{NaCl}$ and re-equilibrated with TC buffer containing $50 \mathrm{mM}$ $\mathrm{NaCl}$. The column was first eluted with $200 \mathrm{mM}$ lysine in TC buffer containing $50 \mathrm{mM} \mathrm{NaCl}$, followed by $750 \mathrm{mM}$ lysine in the same buffer. The column was then re-equilibrated and eluted with $200 \mathrm{mM}$ arginine in the same buffer at a flow rate of $0.1 \mathrm{ml} \mathrm{min}^{-1}$. Peaks were collected and assayed for amidolytic and proteolytic activity. Bz-L-Arg-pNA amidolytic activity is shown by the histogram and the arrows indicate the start of each step gradient.

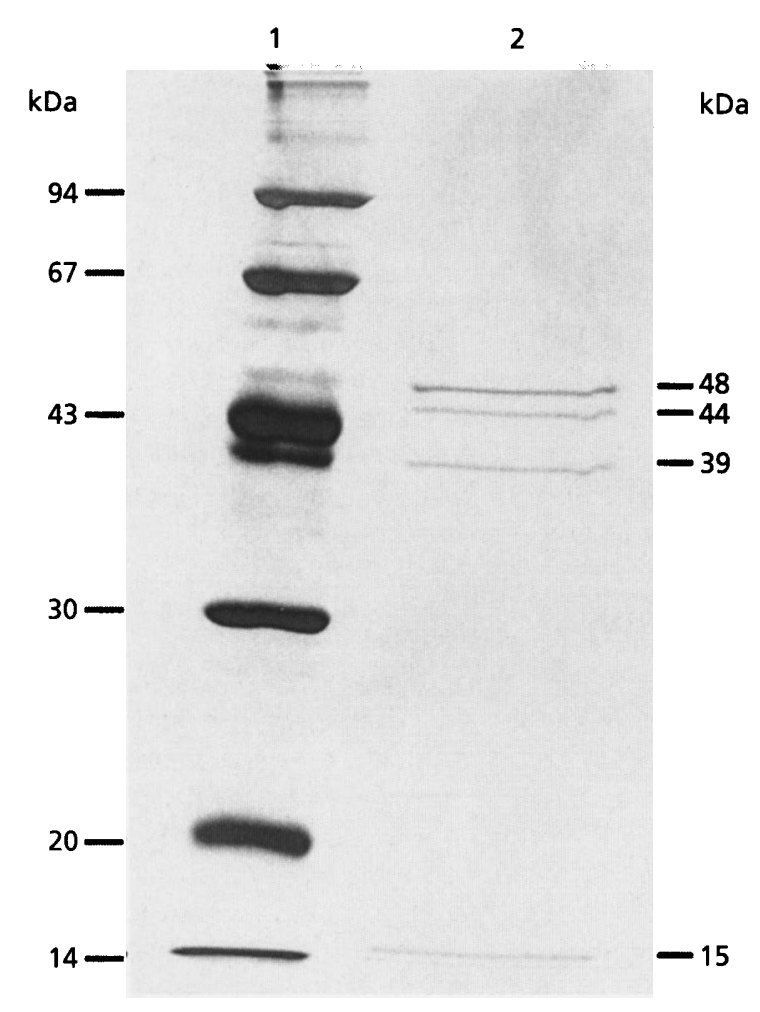

Fig. 6. SDS-PAGE (boiled/reduced conditions) of $200 \mathrm{mM}$ lysine eluant from the Arg-Sepharose FPLC. Lane 1, Pharmacia molecular-mass standards ( $\mathrm{kDa}$ ); lane 2, $200 \mathrm{mM}$ lysine eluant from Arg-Sepharose FPLC. Silver-stained gel.

cleaved except the $\mathrm{N}$-terminal Arg and the Lys residues flanking the $\operatorname{Ser}(P)$ cluster sequence, presumably due to the high negative charge density (Fig. 4). The $300 \mathrm{kDa}$

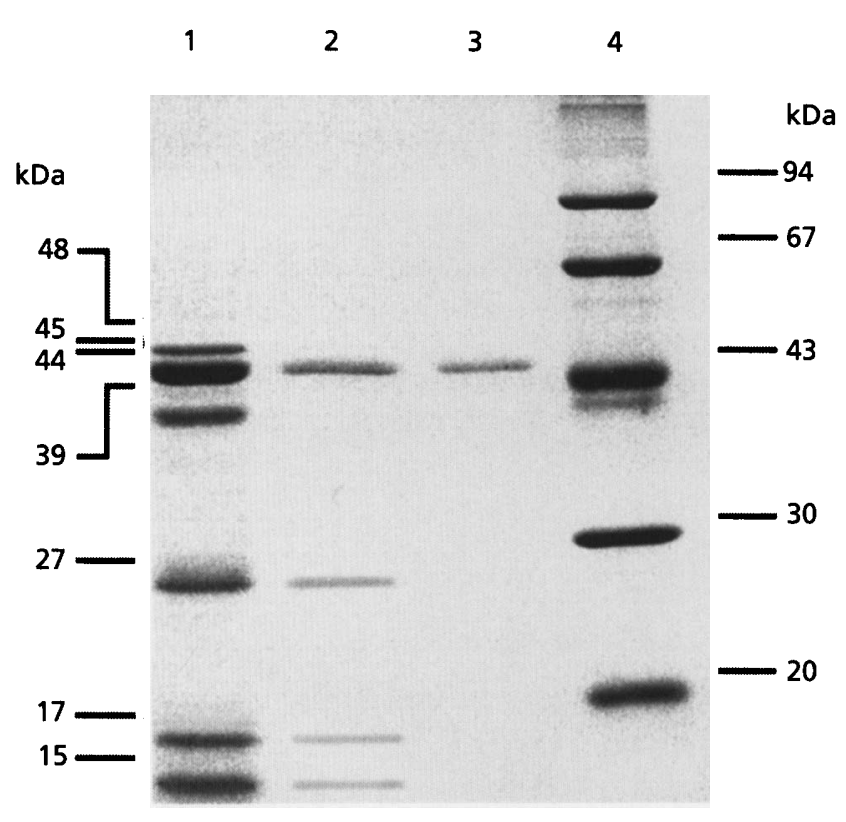

Fig. 7. SDS-PAGE (boiled/reduced conditions) of the $750 \mathrm{mM}$ lysine and $200 \mathrm{mM}$ arginine eluants from the Arg-Sepharose FPLC and the purified $45 \mathrm{kDa}$ Arg-specific proteinase. Lane 1, $750 \mathrm{mM}$ lysine eluant; lane 2, $200 \mathrm{mM}$ arginine eluant; lane 3, purified $45 \mathrm{kDa}$ Arg-specific proteinase; lane 4, Pharmacia molecular-mass standards $(\mathrm{kDa})$. Gel stained with Coomassie blue.

complex was then applied to an Arg-Sepharose column and washed with TC buffer containing $500 \mathrm{mM} \mathrm{NaCl}$ (Fig. 5). The Arg-Sepharose was eluted first with $200 \mathrm{mM}$ lysine in TC buffer (Fig. 5) which eluted a small amount of the $48,44,39$ and $15 \mathrm{kDa}$ proteins of the $300 \mathrm{kDa}$ complex as shown by SDS-PAGE (Fig. 6 and Table 1). N-terminal sequence analysis of these transblotted proteins revealed that only one of the $44 \mathrm{kDa}$ proteins of the $300 \mathrm{kDa}$ complex was eluted with $200 \mathrm{mM}$ lysine (Table 1). This fraction eluted from ArgSepharose with $200 \mathrm{mM}$ lysine contained only Lysspecific proteolytic/amidolytic activity. Next the ArgSepharose column was eluted with $750 \mathrm{mM}$ lysine (Fig. 5 ) which removed the majority of the protein bound as the undissociated $300 \mathrm{kDa}$ complex containing all seven bands (eight proteins) as shown by SDS-PAGE analysis (Fig. 7). The $750 \mathrm{mM}$ lysine eluant exhibited both Argand Lys-specific proteolytic/amidolytic activity characteristic of the $300 \mathrm{kDa}$ complex. The Arg-Sepharose column was then eluted with $200 \mathrm{mM}$ arginine in TC buffer (Fig. 5). The $200 \mathrm{mM}$ arginine eluant contained a small amount of the 45, 44, 27, 17 and $15 \mathrm{kDa}$ proteins as shown by SDS-PAGE (Fig. 7). This fraction exhibited only Arg-specific proteolytic/amidolytic activity. Nterminal sequence analysis of these transblotted proteins eluted with $200 \mathrm{mM}$ arginine revealed that only one of the $44 \mathrm{kDa}$ proteins of the $300 \mathrm{kDa}$ complex was eluted with $200 \mathrm{mM}$ arginine and this $44 \mathrm{kDa}$ protein was different to the $44 \mathrm{kDa}$ protein eluted with $200 \mathrm{mM}$ lysine (Table 1).

The proteins eluted from the Arg-Sepharose column 
Table 2. Purification of the $45 \mathrm{kDa}$ Arg-specific proteinase PrtR45

\begin{tabular}{|c|c|c|c|c|c|}
\hline $\begin{array}{l}\text { Purification } \\
\text { step }\end{array}$ & $\begin{array}{l}\text { Protein } \\
\text { (mg) }\end{array}$ & $\begin{array}{c}\text { Proteolytic } \\
\text { activity } \\
(\mathrm{U})^{*}\end{array}$ & $\begin{array}{c}\text { Specific } \\
\text { activity } \\
\left(\mathbf{U} \mathbf{~ m g}^{-1}\right)\end{array}$ & $\begin{array}{c}\text { Purification } \\
\text { (-fold) }\end{array}$ & $\begin{array}{l}\text { Yield } \\
(\%)\end{array}$ \\
\hline Sonicate & $48 \cdot 0$ & 124 & $2 \cdot 6$ & 1 & 100 \\
\hline $\begin{array}{l}\text { Anion-exchange FPLC } \\
\text { (Q-Sepharose) }\end{array}$ & $8 \cdot 2$ & 64 & $7 \cdot 8$ & 3 & 52 \\
\hline $\begin{array}{l}\text { Gel-filtration FPLC } \\
\quad \text { (Superose 12) }\end{array}$ & 3.9 & 46 & 11.8 & 5 & 37 \\
\hline $\begin{array}{l}\text { Affinity FPLC } \\
\text { (Arg-Sepharose) }\end{array}$ & 0.7 & 17 & $24 \cdot 3$ & 9 & 14 \\
\hline $\begin{array}{l}\text { Anion-exchange FPLC } \\
\text { (Mono Q) }\end{array}$ & $0 \cdot 2$ & 13 & $65 \cdot 0$ & 25 & 11 \\
\hline
\end{tabular}

*Amidolytic activity using $1.0 \mathrm{mM} \mathrm{Bz-L-Arg-pNA} ; 1$ unit $(\mathrm{U})=1 \mu \mathrm{mol} \mathrm{min}{ }^{-1}$ at $25^{\circ} \mathrm{C}$.

Table 3. Effects of various activators/inhibitors on the

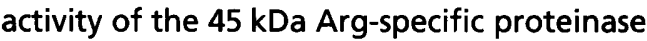

\begin{tabular}{|c|c|c|}
\hline Compound ${ }^{*}$ & $\begin{array}{c}\text { Concentration } \\
(\mathbf{m M})\end{array}$ & $\begin{array}{c}\text { Activity } \\
(\%)\end{array}$ \\
\hline \multirow[t]{3}{*}{ 2-Mercaptoethanol } & $1 \cdot 0$ & 100 \\
\hline & $10 \cdot 0$ & 158 \\
\hline & $50 \cdot 0$ & 189 \\
\hline \multirow[t]{2}{*}{ Dithiothreitol } & $1 \cdot 0$ & 109 \\
\hline & $10 \cdot 0$ & 174 \\
\hline \multirow[t]{3}{*}{ L-Cysteine } & $0 \cdot 1$ & 183 \\
\hline & $1 \cdot 0$ & 320 \\
\hline & $10 \cdot 0$ & 487 \\
\hline \multirow[t]{2}{*}{ PMSF† } & $1 \cdot 0$ & 100 \\
\hline & $10 \cdot 0$ & 90 \\
\hline \multirow[t]{2}{*}{ AEBSF $†$} & $1 \cdot 0$ & 93 \\
\hline & $10 \cdot 0$ & 80 \\
\hline TLCK† & $1 \cdot 0$ & 0 \\
\hline \multirow[t]{2}{*}{ Iodoacetic acid $\dagger$} & $1 \cdot 0$ & 82 \\
\hline & $10 \cdot 0$ & 19 \\
\hline \multirow[t]{2}{*}{ PCMB $†$} & $1 \cdot 0$ & 100 \\
\hline & $10 \cdot 0$ & 14 \\
\hline Leupeptin $†$ & $0 \cdot 1$ & 0 \\
\hline \multirow[t]{3}{*}{ EDTA† } & $1 \cdot 0$ & 100 \\
\hline & $10 \cdot 0$ & 4 \\
\hline & $50 \cdot 0$ & 0 \\
\hline $\mathrm{EDTA}+\mathrm{Ca}^{2+} \dagger$ & $50 \cdot 0$ & 97 \\
\hline$o$-Phenanthroline $\dagger$ & $10 \cdot 0$ & 100 \\
\hline
\end{tabular}

* PCMB, p-chloromercuribenzoic acid; AEBSF, [4-(2-aminoethyl)-benzenesulfonylfluoride], TLCK, N $\alpha$-p-tosyl-L-lysine chloromethyl ketone.

† These incubations also contained 1.0 mM 2-mercaptoethanol.

with $200 \mathrm{mM}$ lysine and $200 \mathrm{mM}$ arginine were washed, concentrated and equilibrated with TC buffer containing $50 \mathrm{mM} \mathrm{NaCl}$ and $1.0 \%$ octyl- $\beta$-D-glucopyranoside and applied independently to a Mono $\mathrm{Q}$ anionexchange column. Elution from the Mono $Q$ column with a $\mathrm{NaCl}$ gradient associated the Arg-specific proteolytic activity with the $45 \mathrm{kDa}$ protein with a 25 -fold purification over the original crude sonicate (Table 2, Fig. 7). The specificity of the $45 \mathrm{kDa}$ proteinase for arginyl residues was confirmed by the enzyme cleaving Bz-L-Arg- $p$ NA but not $z-L-L y s-p N A$. The Arg-specific $45 \mathrm{kDa}$ enzyme was activated by thiols (particularly cysteine), not inhibited by PMSF or 4-(2-aminoethyl)benzenesulphonylfluoride but inhibited by SH-directed reagents, leupeptin and EDTA (Table 3). The inhibition by EDTA could be reversed by the addition of $\mathrm{Ca}^{2+}$ (Table 3). The $\mathrm{pH}$ optimum of the enzyme was $7 \cdot 5-8 \cdot 0$ with activity declining markedly as the $\mathrm{pH}$ was lowered below $7 \cdot 0$. These results indicate that the $45 \mathrm{kDa}$ enzyme is a calcium-stabilized, Arg-specific cysteine proteinase. The Lys-specific activity was characterized using the substrate z-L-Lys- $p$ NA and was associated with the $48 \mathrm{kDa}$ protein purified from the $200 \mathrm{mM}$ lysine eluant by Mono Q FPLC. The Lys-specific enzyme was also activated by thiols and inhibited by $\mathrm{SH}$-directed reagents but was not inhibited by leupeptin or EDTA.

\section{DISCUSSION}

We have purified and characterized a cell-associated $45 \mathrm{kDa}$, Arg-specific, $\mathrm{Ca}^{2+}$-dependent cysteine proteinase and a $48 \mathrm{kDa}$, Lys-specific cysteine proteinase from a sonicate of $P$. gingivalis W50 cells that are components of a $300 \mathrm{kDa}$ complex of non-covalently associated proteins. The proteins of the $300 \mathrm{kDa}$ complex were the $45 \mathrm{kDa}$ and $48 \mathrm{kDa}$ proteinases with six other proteins, two $44 \mathrm{kDa}$ and $39,27,17$ and $15 \mathrm{kDa}$ proteins. The size of the complex $(300 \mathrm{kDa})$ is consistent with the work of Bedi (1995) and Fujimura \& Nakamura (1987) who have partially characterized a $300 \mathrm{kDa}$ cysteine proteinase with trypsin-like specificity from the culture fluid of $P$. gingivalis strains FAY-19M-1 and ATCC 33277, respectively. The protease characterized by Bedi (1995), designated Ala, cleaved on the carboxyl side of both Arg and Lys residues in chromogenic substrates and was inhibited by $\mathrm{SH}$-directed reagents and TLCK. The $300 \mathrm{kDa}$ protease identified by Fujimura \& Nakamura 


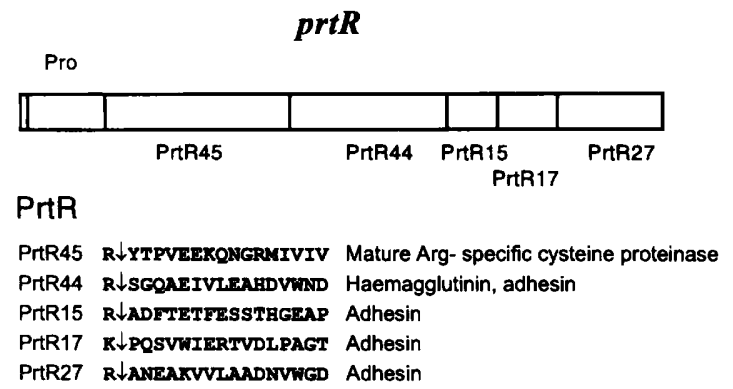

Fig. 8. Schematic representation of the prtR gene. The PrtR nascent polyprotein is composed of a leader sequence, a prosequence followed by the Arg-specific cysteine proteinase PrtR45, and the adhesins PrtR44, PrtR15, PrtR17 and PrtR27 all preceded by an arginyl or lysyl residue (Slakeski et al., 1996; GenBank accession no. L26341).

(1987) exhibited activity against Bz-L-Arg- $p N A$ and was also inhibited by SH-directed reagents and TLCK. It would appear therefore that the $300 \mathrm{kDa}$ cell-associated complex characterized in this present study has characteristics similar to those of the culture fluid enzyme(s) identified by Bedi (1995) and Fujimura \& Nakamura (1987).

The $45,27,17,15 \mathrm{kDa}$ and one of the $44 \mathrm{kDa}$ protein components of the $300 \mathrm{kDa}$ complex are encoded by the recently reported gene, $p r t R$ (GenBank accession no. L26341; Slakeski et al., 1996) as presented schematically in Fig. 8. The prtR gene is similar to the $r g p 1$ gene of $P$. gingivalis H66 reported by Pavloff et al. (1995). Each PrtR component is preceded by an arginyl or lysyl residue (Fig. 8), indicating that the polyprotein is processed by trypsin-like proteolytic activity. We have designated these component parts of the $300 \mathrm{kDa}$ complex, by their relative molecular masses as determined by SDS-PAGE, as PrtR45, PrtR44, PrtR27, PrtR17 and PrtR15 which fit reasonably well with the predicted sizes from the deduced PrtR amino acid sequence $(53.9,44.8,29.5,17.5$ and $14.3 \mathrm{kDa}$ respectively). It is interesting to note that the $44 \mathrm{kDa}$ protein, PrtR44, has been reported by previous workers as a culture fluid haemagglutinin/adhesin (Pike et al., 1994; Curtis et al., 1996). PrtR44 has homology with the other non-proteinase components of the multiprotein complex suggesting a similar role for PrtR27, PrtR17 and PrtR15 in interacting with the proteinase and/or in haemagglutination or adhesion (Slakeski et al., 1996). The PrtR45 Arg-specific proteinase component of the PrtR complex has the same characteristics and $\mathrm{N}$-terminal sequence as the $50 \mathrm{kDa}$ Arg-specific proteinase identified in the culture supernatant of $P$. gingivalis $\mathrm{H} 66$ by Chen et al. (1992) designated Arg-gingipain and also has the same characteristics and N-terminal sequence as the $44 \mathrm{kDa}$ enzyme purified from the culture supernatant of $P$. gingivalis 381 by Okamoto et al. (1995) designated Argingipain. The difference in size between the $44 / 45$ and $50 \mathrm{kDa}$ proteinases probably results from C-terminal truncation of the $50 \mathrm{kDa}$ enzyme as suggested previously (Kirszbaum et al., 1995).
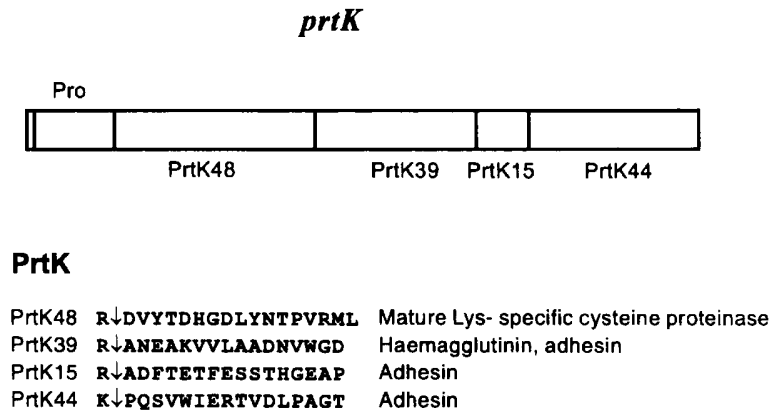

Fig. 9. Schematic representation of the prtK gene. The PrtK nascent polyprotein is composed of a leader sequence, a prosequence followed by the Lys-specific cysteine proteinase PrtK48, and the adhesins PrtK39, PrtK15 and PrtK44 all preceded by an arginyl or lysyl residue (N. Slakeski and others, unpublished; GenBank accession no. U75366).

The other proteins of the $300 \mathrm{kDa}$ complex, the $48 \mathrm{kDa}$ Lys-specific proteinase, the other $44 \mathrm{kDa}$ protein and the $39 \mathrm{kDa}$ protein have recently been shown in this laboratory to be encoded by a single gene, $p r t K$ (unpublished; GenBank accession no. U75366) presented schematically in Fig. 9. prtK is similar to $p r t R$ in that it encodes a putative leader sequence, a prosequence followed by the proteinase domain which is then followed by sequence-related adhesins that have high homology with the C-terminal adhesins of prtR. We have designated the $48 \mathrm{kDa}$ Lys-specific proteinase PrtK48 and its associated adhesins PrtK39, PrtK15 and PrtK44 (Fig. 9) based on the sizes measured by SDSPAGE which fit reasonably well with the predicted sizes from the deduced PrtK amino acid sequence $(55 \cdot 9,44 \cdot 8$, 14.3 and $47.9 \mathrm{kDa}$ respectively). PrtK 48 has the same enzyme characteristics as the $48 \mathrm{kDa}$ proteinase purified from the culture supernatant of $P$. gingivalis 33277 by Fujimura et al. (1993). PrtK48 also has the same Nterminal sequence and enzyme characteristics as the $60 \mathrm{kDa}$ Lys-specific proteinase previously purified from the culture fluid of $P$. gingivalis H66 by Pike et al. (1994) and designated Lys-gingipain. The difference in sizes of these two enzymes again may be attributed to $\mathrm{C}$-terminal truncation. PrtK39, PrtK15 and PrtK44 are all sequencerelated and have high homology with the PrtR haemagglutinins/adhesins particularly the $15 \mathrm{kDa}$ protein which is identical in both gene products, suggesting that these proteins are also haemagglutinins/adhesins.

As the $300 \mathrm{kDa}$ proteinase-adhesin complex and higher molecular mass forms are composed of proteins from the two genes, $p r t R$ and $p r t K$, we suggest that they be designated PrtR-PrtK complexes. The deduced molecular mass of the mature PrtR is $160 \mathrm{kDa}$ (Slakeski et al., 1996) and mature PrtK is $163 \mathrm{kDa}$ (unpublished) such that the mass of the PrtR-PrtK heterodimer would be $323 \mathrm{kDa}$. SDS-PAGE of the sample after boiling produced the seven bands of 48, 45, 44, 39, 27, 17 and $15 \mathrm{kDa}$ corresponding to the domains of the two gene products, PrtR and PrtK. These domains were only seen when the sample was boiled, with or without reducing 
agent, suggesting that the domains remain tightly noncovalently associated after proteolytic processing. The cell sonicate and the chromatographic fractions had minimal or no proteolytic activity in the absence of reducing agents thus ensuring minimal enzymic activity during the chromatographic purifications. Further, the components of the $300 \mathrm{kDa}$ complex were not produced by proteolytic activation during sample preparation in the presence of reducing agent immediately prior to reducing SDS-PAGE as the same pattern of bands was observed on SDS-PAGE in the absence of reducing agent and in the presence of the inhibitor TLCK. The characterization of the $300 \mathrm{kDa}$ cell-associated complex as being composed of processed domains of the two genes $p r t R$ and $p r t K$ suggests that the secreted, mature PrtR and PrtK proteins associate and are processed, perhaps autolytically to form the multiprotein complex. The identification of several of the domains of PrtR and PrtK in the culture supernatant by independent groups (Chen et al., 1992; Pike et al., 1994; Okamoto et al., 1995; Fujimura et al., 1993) is consistent with the proteolytic (autolytic) processing of these polyproteins.

The relative molecular mass of the processed PrtRPrtK heterodimer is likely to be attributable to the composition of 1 PrtK48+1 PrtR45+1 PrtK44+1 PrtR44 + 1 PrtK39 + 1 PrtR27 + 1 PrtR17 + 1 PrtK15 + 1 PrtR15 = 294-323 kDa depending on C-terminal truncation, that is the $300 \mathrm{kDa}$ complex would contain the five domains of $p r t R$ and the four domains of $p r t K$ gene products (Figs 8 and 9). This predicted relative molecular mass of $294-323 \mathrm{kDa}$ is in good agreement with the molecular mass determined by gel filtration and nonboiling SDS-PAGE. As high-molecular-mass material $\left(0.6->2 \times 10^{6} \mathrm{Da}\right)$ on gel filtration (Fig. 2) was also composed of the seven PrtR-PrtK bands then this suggests that the $300 \mathrm{kDa}$ PrtR-PrtK complexes may further associate to form larger cell-associated aggregates. The high amino acid sequence homology between PrtR44, PrtK44, PrtK39, PrtR27, PrtR17 and the $15 \mathrm{kDa}$ protein of both PrtR and PrtK suggests that these adhesins are responsible for the non-covalent cohesive interactions between the components of the PrtR-PrtK complexes and between the complexes themselves in the larger aggregates. It is interesting to note that some dissociation of the $300 \mathrm{kDa}$ PrtR-PrtK complex occurred during the affinity chromatography on Arg-Sepharose, although the majority of the protein eluted as the undissociated complex with $750 \mathrm{mM}$ lysine. The partial dissociation of the complex on binding to substrate may be a mechanism by which the complex targets specific host macromolecules and cells releasing the proteinase/ adhesin domains at the target site on binding.

Ciborowski et al. (1994) have extracted a cell-associated Arg- and Lys-specific proteinase from $P$. gingivalis W12 using the detergent CHAPS. The size of the proteinase, as determined by non-boiling SDS-PAGE, was $150 \mathrm{kDa}$. However, when the sample was boiled in SDS the proteinase separated into smaller components of 20 $50 \mathrm{kDa}$ on SDS-PAGE with one of the components being of similar size and having the same $\mathrm{N}$-terminal sequence as PrtK39. Furthermore, the authors claimed that the enzyme contained two distinct active sites, one for arginyl and one for lysyl residues, based on differential inhibition by leupeptin. As the PrtR-PrtK complex also exhibits a $150 \mathrm{kDa}$ band on non-boiling SDS-PAGE, presumably corresponding to the unprocessed, dissociated forms of the mature PrtR $(160 \mathrm{kDa})$ and mature PrtK $(163 \mathrm{kDa})$ or the partially dissociated complex of processed domains composed of the two proteinase domains and some of the adhesins, then it is likely that the proteinase characterized by Ciborowski et al. (1994) was PrtR-PrtK.

Recently Potempa et al. (1995) using SDS-PAGE (nonboiling) and Western blotting with antibodies against the $50 \mathrm{kDa}$ Arg-specific $P$. gingivalis proteinase from the culture fluid designated Arg-gingipain, suggested that Arg-gingipain exists as a $110 \mathrm{kDa}$ heterotrimer or $95 \mathrm{kDa}$ heterodimer of the proteinase and the $44 \mathrm{kDa}$ haemagglutinin depending on the presence of a $15 \mathrm{kDa}$ protein which was speculated to be a membrane anchor protein. In the present study the $300 \mathrm{kDa}$ PrtR-PrtK on SDS-PAGE without boiling ran approximately as $66 \mathrm{kDa}, 76 \mathrm{kDa}, 87 \mathrm{kDa}, 104-115 \mathrm{kDa}, 150 \mathrm{kDa}$ and $300 \mathrm{kDa}$ bands presumably corresponding to dimers and trimers as well as the intact mature PrtR, PrtK and complex. For example, the fully processed PrtR-PrtK on partial dissociation could give rise to heterotrimers PrtR45 + PrtR44 + PrtR15 = $104 \mathrm{kDa}$, PrtK48 + PrtK39 + PrtK15 = $102 \mathrm{kDa}$, heterodimers PrtK48 + PrtK39 = $87 \mathrm{kDa}$, PrtR45 + PrtR44 = 89 kDa and other similar dimer and trimer combinations of processed domains. Alternatively, the $110-115 \mathrm{kDa}$ forms could arise from incomplete processing of the mature PrtR and PrtK polyproteins. For example, C-terminal truncation of both the mature PrtR and PrtK by loss of the Cterminal PrtR27 + PrtR17 adhesins and PrtK44 adhesin respectively would result in a $113 \mathrm{kDa}$, truncated PrtR and $115 \mathrm{kDa}$, truncated PrtK.

It is apparent therefore that SDS-PAGE without boiling will dissociate the $300 \mathrm{kDa} \operatorname{PrtR}-\operatorname{PrtK}$ complex into dimers and trimers similar to the dimers and trimers found in the culture supernatant of $P$. gingivalis strain H66 by Potempa et al. (1995). It is interesting to speculate that the $15 \mathrm{kDa}$ membrane anchor protein suggested by Potempa et al. (1995) is PrtR15. However, this protein as well as the other components of the PrtR-PrtK complex (Slakeski et al., 1996; N. Slakeski and others, unpublished) do not appear to contain a membrane-spanning hydrophobic sequence using the methods of Kyte \& Doolittle (1982) and Engelman et al. (1986). It is possible that the PrtR-PrtK complex is attached at the cell surface by association with LPS. Boyd \& McBride (1984) have reported the presence of LPS in a crude haemagglutinin preparation from $P$. gingivalis. Furthermore, Okuda et al. (1986) purified a $40-60 \mathrm{kDa}$ haemagglutinin from $P$. gingivalis 381 that was inhibited by arginine and lysine and was composed of $73 \%$ protein, $12 \%$ sugar and $6 \%$ phosphorus possibly suggesting the presence of bound LPS. Okuda et al. (1986) also observed that the haemagglutinin 
aggregated to form large complexes which is consistent with the results of the present study.

In conclusion, we have characterized the major cellassociated Arg-specific and Lys-specific proteolytic activity of $P$. gingivalis as a complex of two proteinases and sequence-related adhesins encoded by the two genes, $p r t R$ and $p r t K$. It is proposed that this proteinaseadhesin complex is a major virulence factor for $P$. gingivalis involved in the evasion of host defence and in the assimilation of haem and peptides.

\section{ACKNOWLEDGEMENTS}

This research was supported by an Australian National Health and Medical Research Council Dental Postgraduate Scholarship for P.S.B. and by the Australian National Health and Medical Research Council project grants no. 930687 and no. 960231. We gratefully acknowledge Peter Riley, David Stanton and Kaylene Quelch for expert technical assistance and Louis Kirszbaum for valuable discussions.

\section{REFERENCES}

Bedi, G. S. (1995). Comparative study of four proteases from spent culture media of Porphyromonas gingivalis (FAY-19M-1). Prep Biochem 25, 133-154.

Boyd, J. \& McBride, B. C. (1984). Fractionation of hemagglutinating and bacterial binding adhesins of Bacteroides gingivalis. Infect Immun 45, 403-409.

Carlsson, J., Herrmann, B. F., Hofling, J. F. \& Sundqvist, G. K. (1984). Degradation of the human proteinase inhibitors alpha-1anti trypsin and alpha-2-macroglobulin by Bacteroides gingivalis. Infect Immun 43, 644-648.

Chen, Z., Potempa, J., Polanowski, A., Wikstrom, M. \& Travis, J. (1992). Purification and characterization of a $50-\mathrm{kDa}$ cysteine proteinase (gingipain) from Porphyromonas gingivalis. J Biol Chem 267, 18896-18901.

Christersson, L. A., Zambon, J. J., Dunford, R. G., Grossi, S. G. \& Genco, R. J. (1989). Specific subgingival bacteria and diagnosis of gingivitis and periodontitis. J Dent Res 68, 1633-1639.

Ciborowski, P., Nishikata, M., Allen, R. D. \& Lantz, M. S. (1994). Purification and characterization of two forms of a highmolecular-weight cysteine proteinase (Porphypain) from Porphyromonas gingivalis. J Bacteriol 176, 4549-4557.

Curtis, M. A., Aduse-Opoku, J., Slaney, J. M., Rangarajan, M., Booth, V., Cridland, J. \& Shepherd, P. (1996). Characterization of an adherence and antigenic determinant of the ArgI protease of Porphyromonas gingivalis which is present on multiple gene products. Infect Immun 64, 2532-2539.

Cutler, C. W., Kalmar, J. R. \& Genco, C. A. (1995). Pathogenic strategies of the oral anaerobe, Porphyromonas gingivalis. Trends Microbiol 3, 45-51.

Engelman, D. M., Steitz, T. A. \& Goldman, A. (1986). Identifying non-polar transbilayer helices in amino acid sequences of membrane proteins. Annu Rev Biophys Biophys Chem 15, 321-353.

Fujimura, S. \& Nakamura, T. (1987). Isolation and characterization of a protease from Bacteroides gingivalis. Infect Immun 55, 716-720.

Fujimura, S., Shibata, Y. \& Nakamura, T. (1993). Purification and partial characterization of a lysine-specific protease of Porpbyromonas gingivalis. FEMS Microbiol Lett 113, 133-138.
Grenier, D. (1996). Degradation of host protease inhibitors and activation of plasminogen by proteolytic enzymes from Porphyromonas gingivalis and Treponema denticola. Microbiology 142, 955-961.

Grenier, D. \& Mayrand, D. (1993). Proteinases. In Biology of the Species Porphyromonas gingivalis, pp. 227-244. Edited by H. N. Shah. Boca Raton, FL: CRC Press.

Grenier, D., Mayrand, D. \& McBride, B. C. (1989). Further studies on the degradation of immunoglobulins by black-pigmented Bacteroides. Oral Microbiol Immun 4, 12-18.

Holt, S. C., Ebersole, J., Felton, J., Brunsvold, M. \& Korman, K. S. (1988). Implantation of Bacteroides gingivalis in non-human primates initiates progression of periodontitis. Science 239, 55-57.

Imamura, T., Pike, R. N., Potempa, J. \& Travis, J. (1994). Pathogenesis of periodontitis: a major arginine-specific cysteine proteinase from Porphyromonas gingivalis induces vascular permeability enhancement through activation of the kallikinin pathway. J Clin Invest 94, 361-367.

Imamura, T., Potempa, J., Pike, R. N., Moore, J. N., Barton, M. H. \& Travis, J. (1995a). Effect of free and vesicle-bound cysteine proteinases of Porphyromonas gingivalis on plasma clot formation: implications for bleeding tendency at periodontitis sites. Infect Immun 63, 4877-4882.

Imamura, T., Potempa, J., Pike, R. N. \& Travis, J. (1995b). Dependence of vascular permeability enhancement on cysteine proteinases in vesicles of Porphyromonas gingivalis. Infect Immun 63, 1999-2003.

Jagels, M. A., Travis, J., Potempa, J., Pike, R. \& Hugli, T. E. (1996). Proteolytic inactivation of the leukocyte C5a receptor by proteinases derived from Porphyromonas gingivalis. Infect Immun 64, 1984-1991.

Kadowaki, T., Yoneda, M., Okamoto, K., Maeda, K. \& Yamamoto, K. (1994). Purification and characterization of a novel argininespecific cysteine proteinase (argingipain) involved in the pathogenesis of periodontal disease from the culture supernatant of Porphyromonas gingivalis. J Biol Chem 269, 21371-21378.

Kesavalu, L., Holt, S. C. \& Ebersole, J. L. (1996). Trypsin-like protease activity of Porphyromonas gingivalis as a potential virulence factor in a murine lesion model. Microb Pathog 20, 1-10.

Kirszbaum, L., Sotiropoulos, C., Jackson, C., Cleal, S., Slakeski, N. \& Reynolds, E. C. (1995). Complete nucleotide sequence of a gene prtR of Porphyromonas gingivalis W50 encoding a $132 \mathrm{kDa}$ protein that contains an arginine-specific, thiol endopeptidase domain and a haemagglutinin domain. Biochem Biophys Res Commun 207, 424-431.

Kyte, J. \& Doolittle, R. F. (1982). A simple method for displaying the hydropathic character of a protein. J Mol Biol 157, 105-132.

Laemmli, U. K. (1970). Cleavage of structural proteins during the assembly of the head of bacteriophage T4. Nature 227, 680-685.

Lantz, M. S., Allen, R. D., Vail, T. A., Switalski, L. M. \& Hook, M. (1991). Specific cell components of Bacteroides gingivalis mediate binding and degradation of human fibrinogen. J Bacteriol 173, 495-504.

Loesche, W. J., Syed, S. A., Morrison, E. C., Laughon, B. \& Grossman, N. S. (1981). Treatment of periudontal infections due to anaerobic bacteria with short-term treatment with metronidazole. J Clin Periodontol 8, 29-44.

Marsh, P. D., McDermid, A. S., McKee, A. S. \& Baskerville, A. (1994). The effect of growth rate and haemin on the virulence and proteolytic activity of Porphyromonas gingivalis W50. Microbiology 140, 861-865. 
McKee, A. S., McDermid, A. S., Baskerville, A., Dowsett, B., Ellwood, D. C. \& Marsh, P. D. (1986). Effect of hemin on the physiology and virulence of Bacteroides gingivalis W50. Infect Immun 52, 349-355.

McKee, A. S., McDermid, A. S., Wait, R. \& Baskerville, A. (1988). Isolation of colonial variants of Bacteroides gingivalis W50 with reduced virulence. J Med Microbiol 27, 59-64.

Mayrand, D. \& Holt, S. C. (1988). Biology of asaccharolytic blackpigmented Bacteroides species. Microbiol Rev 52, 134-152.

Merril, C. R., Goldman, D. \& Van Keuren, M. L. (1982). Simplified silver protein detection and image enhancement methods in polyacrylamide gels. Electrophoresis 3, 14-23.

Moore, W. E. C., Moore, L. H., Ranney, R. R., Smibert, R. M., Burmeister, J. A. \& Schenkein, H. A. (1991). The microflora of periodontal sites showing active destructive progression. J Clin Periodontol 18, 729-739.

Neuhoff, V., Stamm, R. \& Eibl, H. (1985). Clear background and highly sensitive protein staining with coomassie blue dyes in polyacrylamide gels: a systematic analysis. Electrophoresis 6, 427-448.

Okamoto, K., Misumi, Y., Kadowaki, T., Yoneda, M., Yamamoto, K. \& Ikehara, Y. (1995). Structural characterization of argingipain, a novel arginine-specific cysteine proteinase as a major periodontal pathogenic factor from Porphyromonas gingivalis. Arch Biochem Biophys 316, 917-925.

Okuda, K., Yamamoto, A., Naito, Y., Takazoe, I., Slots, J. \& Genco, R. J. (1986). Purification and properties of a hemagglutinin from culture supernatant of Bacteroides gingivalis. Infect Immun 54, 659-665.

Pavloff, N., Potempa, J., Pike, R. N., Prochazka, V., Kiefer, M. C., Travis, J. \& Barr, P. (1995). Molecular cloning and structural characterization of the Arg-gingipain proteinase of Porphyromonas gingivalis. J Biol Chem 270, 1007-1010.

Persson, G. R., Engel, D., Whitney, G., Darveau, R., Weinberg, A., Brunsvold, M. \& Page, R. C. (1994). Immunization against Porphyromonas gingivalis inhibits progression of experimental periodontitis in non-human primates. Infect Immun 62, 10261031.

Pike, R., McGraw, W., Potempa, J. \& Travis, J. (1994). Lysine- and arginine-specific proteinases from Porphyromonas gingivalis. J Biol Chem 269, 406-411.

Pike, R. N., Potempa, J., McGraw, W., Coetzer, T. H. T. \& Travis, J. (1996). Characterization of the binding activities of proteinaseadhesin complexes from Porphyromonas gingialis. J Bacteriol 178, 2876-2882.

Potempa, J., Pike, R. \& Travis, J. (1995). The multiple forms of trypsin-like activity present in various strains of Porphyromonas gingivalis are due to the presence of either arg-gingipain or lysgingipain. Infect Immun 63, 1176-1182.

Reynolds, E. C. (1987). The prevention of sub-surface demineralization of bovine enamel and change in plaque composition by casein in an intra-oral model. J Dent Res 66, 1120-1127.
Reynolds, E. C., Riley, P. F. \& Adamson, N. J. (1994). A selectiveprecipitation purification procedure for multiple-phosphoseryl containing peptides and methods for their identification. Anal Biochem 217, 277-284.

Slakeski, N., Cleal, S. M. \& Reynolds, E. C. (1996). Characterization of a Porphyromonas gingivalis gene prt $R$ that encodes an arginine-specific thiol proteinase and multiple adhesins. Biochem Biophys Res Commun 224, 605-610.

Slots, J. (1982). Importance of black pigmented Bacteroides in human periodontal disease. In Host-Parasite Interactions in Periodontal Diseases, pp. 27-45. Edited by R. J. Genco \& S. E. Merganhagan, Washington DC: American Society for Microbiology.

Smalley, J. W., Shuttleworth, C. A. \& Birss, A. J. (1989a). Collagenolytic activity of the extracellular vesicles of Bacteroides gingivalis W50 and an avirulent variant W50/BE1. Arch Oral Biol 34, 579-583.

Smalley, J. W., Birss, A. J., Kay, H. M., McKee, A. S. \& Marsh, P. D. (1989b). The distribution of trypsin-like enzyme activity in cultures of a virulent and an avirulent strain of Bacteroides gingivalis W50. Oral Microbiol Immunol 4, 178-181.

Socransky, S. S., Haffajee, A. D., Smith, C. \& Dibart, S. (1991). Relation of counts of microbial species to clinical status at the sampled site. J Clin Periodontol 18, 766-775.

Sorsa, T., Uitto, V.-J., Suomalainen, K., Turto, H. \& Lindy, S. (1987). A trypsin-like protease from Bacteroides gingivalis: partial purification and characterization. J Periodontal Res 22, 375-380.

Sundqvist, G., Carlsson, J., Herrmann, B. \& Tarnvik, A. (1985). Degradation of human immunoglobulins $G$ and $M$ and complement factors $\mathrm{C} 3$ and $\mathrm{C} 5$ by black-pigmented Bacteroides. J Med Microbiol 19, 85-94.

Toda, K., Otsuka, M., Ishikawa, Y., Sato, M., Yamamoto, Y. \& Nakamura, R. (1984). Thiol-dependent collagenolytic activity in culture media of Bacteroides gingivalis. J Periodontal Res 19, 372-381.

Van Dyke, T. E., Offenbacher, S., Place, D., Dowell, V. R. \& Jones, J. (1988). Refractory periodontitis: mixed infection with Bacteroides gingivalis and other unusual Bacteroides species. J Periodontol 59, 184-189.

Wingrove, J., DiScipio, R. G., Chen, Z., Potempa, J., Travis, J. \& Hugli, T. E. (1992). Activation of complement components C3 and C5 by a cysteine proteinase (Gingipain-1) from Porphyromonas (Bacteroides) gingivalis. J Biol Chem 267, 18902-18907.

Yoshimura, F., Nishikata, M., Suzuki, T., Hoover, C. I. \& Newbrun, E. (1984). Characterization of a trypsin-like protease from the bacterium Bacteroides gingivalis isolated from human dental plaque. Arch Oral Biol 29, 559-564.

Received 1 November 1996; revised 18 March 1997; accepted 25 March 1997. 